\title{
Dose-Dependent Reduction in Pulmonary Vascular Resistance With Epoprostenol in Pulmonary Arterial Hypertension
}

\author{
Satoshi Homma, MD, PhD
}

$\mathbf{P}$ rostacyclin ( $\mathrm{PGI}_{2}$ ), discovered by Moncada et al in $1976,{ }^{1}$ is one of the most potent intrinsic vasodilators with antiproliferative effects and is produced by endothelial cells. Endothelial cells also secrete one of the most potent intrinsic vasoconstrictors with smooth muscle mitogen effects, endothelin (ET), discovered by Yanagisawa et al in 1988. ${ }^{2}$ Both of these discoveries strongly promoted further developments in the field of vascular biology, in which the endothelium might have an important role to play in governing peripheral blood flow.

\section{Article p2200}

These biological developments resulted in clinical application after the 1980s. A typical example is epoprostenol (EPO; Flolan, Glaxo Smith Kline, Brentford, UK), which became commercially available in the United States in 1995 and in Japan in 1999, and created a new era in the treatment of patients with pulmonary arterial hypertension $(\mathrm{PAH})$.

PAH is characterized by a progressive increase in pulmonary vascular resistance (PVR) that eventually leads to right ventricular failure and death. The median survival of patients entered in the NIH registry has been reported as 2.8 years after diagnosis. ${ }^{3}$

Endothelial dysfunction is common in $\mathrm{PAH}$, and includes increased production of vasoconstrictor/mitogenic compounds such as ET and thromboxane, and decreased production of vasodilator/antiproliferative substances such as PGI $2 ., 5$ Therefore, EPO therapy was theoretically hypothesized to improve the hemodynamics and vascular remodeling observed in patients with PAH.

After the advent of EPO, numerous reports confirmed that its infusion decreased pulmonary arterial pressure and increased cardiac output, resulting in a decrease in PVR or total PVR (TPR) and improved exercise capacity as well as quality of life (QOL). Moreover, with intravenous EPO, survival rates were improved compared with historical controls with idiopathic PAH..$^{6-8}$ Thus, EPO has been the mainstay of PAH therapy for more than a decade. To use EPO more effectively in the clinical situation, it is necessary to understand the specific action of EPO in the various forms of PAH.

In $1997 \mathrm{Califf}_{\mathrm{et}} \mathrm{al}^{9}$ noticed a critical adverse result of EPO therapy in patients with left ventricular (LV) failure. They administered EPO $\left(4.0 \mathrm{ng} \cdot \mathrm{kg}^{-1} \cdot \mathrm{min}^{-1}\right)$ to 237 patients with severe LV failure and although the cardiac index increased from 1.81 to $2.61 \mathrm{~L} \cdot \mathrm{min}^{-1} \cdot \mathrm{m}^{-2}$, pulmonary capillary wedge pressure decreased from 24.5 to $20.0 \mathrm{mmHg}$, and systemic vascular resistance decreased from 20.8 to 12.3 Wood units, so the trial was terminated early because of the increased death rate (48\% in 6 months) and no improvement in walking distance or QOL. A critical adverse result for patients with this type of secondary pulmonary hypertension $(\mathrm{PH})$ stands in sharp contrast to the benefits of EPO in cases of idiopathic $\mathrm{PH}$. The reason for this contrast is not yet fully understood.

In 1999 Rich and McLaughlin ${ }^{10}$ discussed excessive doses of EPO. They described how a high cardiac output state (12 of 55 patients) produced by EPO could be changed from $7.4 \pm 1.4$ to $4.0 \pm 0.7 \mathrm{~L} \cdot \mathrm{min}^{-1} \cdot \mathrm{m}^{-2}$ without worsening the patient's clinical state by reducing the EPO dose from $98 \pm 61$ to $60 \pm 50 \mathrm{ng} \cdot \mathrm{kg}^{-1} \cdot \mathrm{min}^{-1}$. Based on this report, approximately $40-60 \mathrm{ng} \cdot \mathrm{kg}^{-1} \cdot \mathrm{min}^{-1}$ has been considered as the maximum range of the EPO dosage.

In 2002 Sitbon et $\mathrm{al}^{11}$ made a detailed and comprehensive report on the efficacy of EPO. They described 178 patients with PAH in New York Heart Association (NYHA) functional class III or IV with EPO (14 $\pm 4-21 \pm 7$ (range 8-40) $\left.\mathrm{ng} \cdot \mathrm{kg}^{-1} \cdot \mathrm{min}^{-1}\right)$ and, after 1 year, mean pulmonary artery pressure (mPA) decreased from $68 \pm 14$ to $60 \pm 12 \mathrm{mmHg}$, TPR from $37.3 \pm 10.5$ to $25.0 \pm 6.9$ Wood units (TPR ratio $67 \%$ after EPO), and the 5-year survival ratio increased to $55 \%$. They also reported that the baseline variables associated with a poor outcome were a history of right heart failure, NYHA functional class IV, 6-min walk distance $\leq 250 \mathrm{~m}$, right atrial pressure $\geq 12 \mathrm{mmHg}$ etc. From their report, the limitation of EPO (dose $\leq 40 \mathrm{ng} \cdot \mathrm{kg}^{-1} \cdot \mathrm{min}^{-1}$ ) was recognized, leading to a proposal of combination therapy, which had the effect of minimizing the number of monotherapy-oriented studies.

In this issue of the Journal, Akagi et al proposed a new therapeutic strategy for implementing high-dose EPO monotherapy. ${ }^{12}$ They reported that 14 patients with PAH in NYHA functional class III or IV were treated with high-dose ( $>40 \mathrm{ng}$. $\left.\mathrm{kg}^{-1} \cdot \mathrm{min}^{-1}\right)$ EPO $\left(107 \pm 40\right.$ (range 54-190) $\mathrm{ng} \cdot \mathrm{kg}^{-1} \cdot \mathrm{min}^{-1}$ ) for $1,355 \pm 627$ days, and that mPA decreased from $66 \pm 16$ to $47 \pm$ $12 \mathrm{mmHg}$, PVR from $21.6 \pm 8.3$ to $6.9 \pm 2.9$ Wood units, and more importantly, all the patients survived for a period of 3.7 years.

Hemodynamic improvement in PAH is indicated by PVR (TPR) reduction. Figure shows the relationship between

The opinions expressed in this article are not necessarily those of the editors or of the Japanese Circulation Society.

Received August 22, 2010; accepted August 23, 2010; released online September 11, 2010

Department of Cardiovascular Medicine, Graduate School of Comprehensive Human Sciences, University of Tsukuba, Tsukuba, Japan

Mailing address: Satoshi Homma, MD, PhD, Department of Cardiovascular Medicine, Graduate School of Comprehensive Human Sciences, University of Tsukuba, 1-1-1 Tennodai, Tsukuba 305-8575, Japan. E-mail: homma-s@md.tsukuba.ac.jp

ISSN-1346-9843 doi:10.1253/circj.CJ-10-0854

All rights are reserved to the Japanese Circulation Society. For permissions, please e-mail: cj@j-circ.or.jp 


\section{EPO dose and PVR (TPR) ratio after EPO}

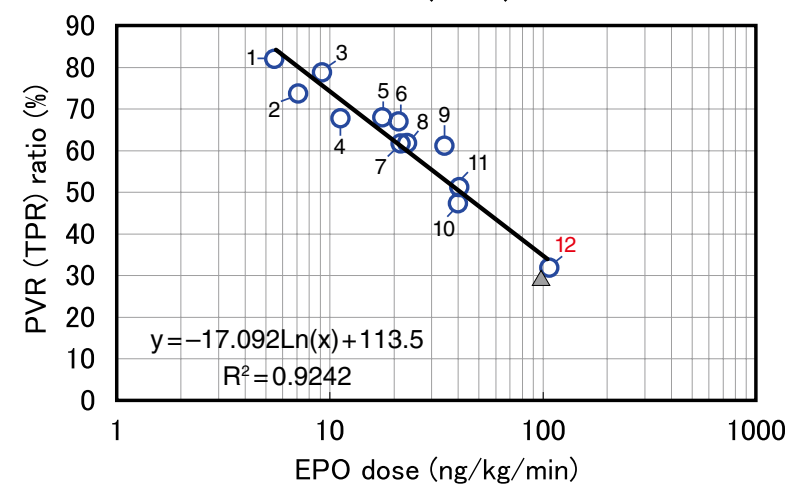

1 Jones DK et al.

2 Rubin LJ et al.

Barst RJ et al. $\quad 1996$

4 Badesch DB et al. 2000

5 Barst RJ et al. 1994

6 Sitbon $O$ et al. 2002

7 Nakayama T et al. 2007

8 Kuhn KP et al. 2003

9 McLaughlin et al. 2002

10 McLaughlin et al. 1998

11 Sakuma M et al. 2009

12 Akagi $S$ et al. 2010

$\triangle$ Rich S et al. $\quad 1999$
Figure. Relationship between dose of epoprostenol (EPO) and PVR (TPR) ratio after EPO monotherapy. The effect of EPO on PVR reduction may be dose-dependent over a wider range than expected. Each point represents a result from an EPO monotherapy study. $\triangle$ Record of selected 12 patients who presented in a state of high cardiac output. PVR, pulmonary vascular resistance; TPR, total pulmonary vascular resistance.
EPO dose $\left(\mathrm{ng} \cdot \mathrm{kg}^{-1} \cdot \mathrm{min}^{-1}\right)$ and the PVR (TPR) ratio (\%) after EPO in previously reported studies of EPO monotherapy. ${ }^{6-8,11-15}$ A statistically significant exponent relationship was observed $\left(\mathrm{R}^{2}=0.92\right)$. In the 2 studies of high-dose EPO therapy, PVR showed almost the same ratio after EPO of approximately $30 \% . .^{10,12}$ And, more importantly, none of the patients died in either of those studies, despite having severe PAH in which the baseline PVR was 12.8 and 21.6 Wood units, respectively. ${ }^{10,12}$

It is, of course, important that patients receiving high-dose EPO should be closely monitored for side-effects. Akagi et al used cardiotonic drugs, including 3-5 $\gamma$ dobutamine when systolic blood pressure could not be kept above $90 \mathrm{mmHg}$, or when the value of $\mathrm{SvO}_{2}$ was less than $60 \%$, or when right heart failure was not improved. They also gave intensive supportive treatment to patients to help them tolerate the sideeffects during the infusion of high-dose EPO, including jaw pain, leg pain, headache, flushing, eruption, nausea and diarrhea. After all these efforts of the patients and the therapeutic team, the target dosages were achieved. ${ }^{12}$

Many medications other than EPO are now available or will be available in the near future, such as ET receptor antagonists, phosphodiesterase inhibitors, soluble guanylate cyclase stimulator, several growth factor inhibitors etc. Although the new era is welcomed, we do not yet have a thorough understanding of the new drugs' usages and interactions contributing to improved QOL and prolonged lifespan, and it may also still be difficult to achieve longer survival for the present patients with severe PAH.

One of the challenging trials, the high-dose EPO monotherapy report from Japan leads us to conclude that the effect of EPO on PVR reduction may be dose-dependent over a wider range than we expected (Figure), which will strongly encourage future exploration of effective treatment options for managing patients with severe $\mathrm{PAH}$.

\section{References}

1. Moncada S, Gryglewski R, Bunting S, Vane JR. An enzyme isolated from arteries transforms prostaglandin endoperoxides to an unstable substance that inhibits platelet aggregation. Nature 1976; 263: $663-665$.

2. Yanagisawa M, Kurihara H, Kimura S, Tomobe Y, Kobayashi M,
Mitsui Y, et al. A novel potent vasoconstrictor peptide produced by vascular endothelial cells. Nature 1988; 332: 411-415.

3. D'Alonzo GE, Barst RJ, Ayres SM, Bergofsky EH, Brundage BH, Detre KM, et al. Survival in patients with primary pulmonary hypertension: Results from a national prospective registry. Ann Intern Med 1991; 115: 343-349.

4. Christman BW, McPherson CD, Newman JH, King GA, Bernard GR, Groves BM, et al. An imbalance between the excretion of thromboxane and prostacyclin metabolites in pulmonary hypertension. N Engl J Med 1992; 327: 70-75.

5. Giaid A, Yanagisawa M, Langleben D, Michel RP, Levy R, Shennib $\mathrm{H}$, et al. Expression of endothelin-1 in the lungs of patients with pulmonary hypertension. $N$ Engl J Med 1993; 328: 1732-1739.

6. Jones DK, Higenbottam TW, Wallwork J. Treatment of primary pulmonary hypertension with intravenous epoprostenol (prostacyclin). Br Heart J 1987; 57: 270-278.

7. Barst RJ, Rubin LJ, Long WA, McGoon MD, Rich S, Badesch $\mathrm{DB}$, et al. A comparison of continuous intravenous epoprostenol (prostacyclin) with conventional therapy for primary pulmonary hypertension: The Primary Pulmonary Hypertension Study Group. N Engl J Med 1996; 334: 296-302.

8. McLaughlin VV, Shillington A, Rich S. Survival in primary pulmonary hypertension: The impact of epoprostenol therapy. Circulation 2002; 106: $1477-1482$.

9. Califf RM, Adams KF, McKenna WJ, Gheorghiade M, Uretsky BF, McNulty SE, et al. A randomized controlled trial of epoprostenol therapy for severe congestive heart failure: The Flolan International Randomized Survival Trial (FIRST). Am Heart J 1997; 134: 4454.

10. Rich S, McLaughlin VV. The effects of chronic prostacyclin therapy on cardiac output and symptoms in primary pulmonary hypertension. J Am Coll Cardiol 1999; 34: 1184-1187.

11. Sitbon O, Humbert M, Nunes H, Parent F, Garcia G, Hervé P, et al. Long-term intravenous epoprostenol infusion in primary pulmonary hypertension: Prognostic factors and survival. J Am Coll Cardiol 2002; 40: 780-788.

12. Akagi S, Nakamura K, Miyaji K, Ogawa A, Kusano KF, Ito H, et al. Marked hemodynamic improvements by high-dose epoprostenol therapy in patients with idiopathic pulmonary arterial hypertension. Circ J 2010; 74: 2200-2205.

13. Kuhn KP, Byrne DW, Arbogast PG, Doyle TP, Loyd JE, Robbins IM. Outcome in 91 consecutive patients with pulmonary arterial hypertension receiving epoprostenol. Am J Respir Crit Care Med 2003; 167: 580-586.

14. Nakayama T, Shimada H, Takatsuki S, Hoshida H, Ishikita T, Matsuura $\mathrm{H}$, et al. Efficacy and limitations of continuous intravenous epoprostenol therapy for idiopathic pulmonary arterial hypertension in Japanese children. Circ J 2007; 71: 1785-1790.

15. Sakuma M, Demachi J, Nawata J, Suzuki J, Takahashi T, Shirato K. Long-term epoprostenol therapy in pulmonary artery hypertension. Circ J 2009; 73: 523-529. 